\title{
PENDIDIKAN KEAGAMAAN \\ DAN KOMUNITAS MUSLIM INDONESIA DI INGGRIS
}

\section{RELIGIOUS EDUCATION AND INDONESIAN MUSLIM COMMUNITY IN THE UNITED KINGDOM}

\author{
Arifuddin Ismail \\ Balai Penelitian dan Pengembangan Agama Makassar \\ Kantor Jl. A. P. Petta Rani 72 Makassar \\ E-mail:arif_litbang@yahoo.com
}

Naskah diterima 3 Maret 2016, direvisi 20 Maret 2016, disetujui 15 April 2016

\begin{abstract}
This study aims to describe the religious life of Indonesian Muslims who live in the United Kingdom, particularly in relation to religious education. This study uses descriptive method with qualitative approach. Depth interview was used as the data collection means. It was found that, first, the formation of the Indonesian citizens association in the United Kingdom (UK) is the answer to the fulfillment of spiritual needs, especially religious spiritual need. Secondly, the condition of schools in the UK creates anxiety for Indonesian parents, because there are other needs, especially religious education needs that are not met. One alternative to deal with this is by joining groups of Muslim community, as an alternative to religious education. This indicates that someone will always strive to meet his psychological needs, particularly when it is in a condition that is different from usual. The implementation of spiritual fulfillment is still limited, but with spirit and a strong desire, the fulfillment can be done.
\end{abstract}

Keywords: Religious Education, Indonesian Muslim Community, United Kingdom

\begin{abstract}
Abstrak
Penelitian ini bertujuan menggambarkan kehidupan keagamaan muslim Indonesia yang berdomisili di United Kingdom, terutama dalam kaitannya dengan pendidikan keagamaan. Penelusuran ini menggunakan metode deskriptif, dengan pendekatan kualitatif. Teknik wawancara mendalam digunakan sebagai alat pengumpulan data. Ternyata ditemukan, pertama, terbentuknya kelompok Paguyuban warga negara Indonesia di Inggris (United Kingdom) merupakan jawaban atas pemenuhan kebutuhan rohani, khususnya siraman rohani keagamaan. Kedua, Kondisi persekolahan di Inggris membuat kegelisahan bagi para orang tua murid dari Indonesia, karena ada kebutuhan lain, terutama kebutuhan pendidikan keagamaanyang tidakterpenuhi. Salah satu alternatifnya adalah dengan bergabung di kelompok paguyuban muslim Indoensia, sebagai alternatif mendapatkan pendidikan keagamaan. Ini mengindikasikan bahwa kebutuhan psikologis sesorang akan selalu diupayakan pemenuhannya, terutama ketika berada di suatu kondisi yang berbeda dari biasanya. Implementasi dari pemenuhan kebutuhan rohaniah memang masih terbatas, tetapi dengan modal semangat dan keinginan yang kuat, pelayanan bisa dilakukan.
\end{abstract}

Kata kunci: Pendidikan Keagamaan, Komunitas Muslim Indonesia, Inggris 


\section{PENDAHULUAN}

Ada pemahaman yang berkembang di kalangan umat beragama di Indonesia, bahwa di negara-negara yang mengklaim dirinya sebagai negara sekuler memiliki tingkat kepedulian yang rendah terhadap agama. Pandangan seperti itu berdasar pada informasi sebelumnya dari hasil bacaan terhadap literatur dan informasi dari media sosial, terutama yang terkait dengan kebijakan di beberapa negara Barat terhadap umat beragama, khususnya Islam; dan kebijakan beberapa negara Barat tentang aturan main bagi umat beragama, misalnya "penggunaan Jilbab", dan aturan tentang diperbolehkannya perkawinan sejenis. Dari sudut pandang keberagamaan memperkuat asumsi dan mengindikasikan bahwa kebijakan tersebut adalah "kebijakan sekuler", yaitu suatu kebijakan yang tidak mempedulikan nilai agama.

Dari sisi lain ada kebijakan dari negara Barat yang dianggap merugikan umat beragama, khususnya umat Islam, tetapi ada juga kebijakan yang menguntungkan, seperti memberi peluang terhadap umat beragama untuk menjalankan kegiatan keagamaan sesuai keyakinan masingmasing. Bahkan umat beragama diberi "ruang" dan "kesempatan" untuk merancang pembelajaran agama dan mengajarkannya di sekolah dan masyarakat. Ini dimasksudkan dalam kaitannya dengan pemberian kesempatan terhadap umat beragama. Bahkan lebih dari itu, sebagai warga negara atau tamu yang bermukim dan berbeda agama diupayakan memberi kepuasan. Prinsip pemberian kesempatan inilah yang dimaksudkan oleh Safriadi bahwa pelayanan di dalamnya terdapat proses yang berimplikasi soaial. ${ }^{1}$ Kemudian diperjelas oleh Daviddow dan Utal bahwa pemberian pelayanan dimaksudkan ke arah pemberian kepuasan terhadap yang dilayani (whatever, enhanices customer satifaction) ${ }^{2}$. Konsep pelayanan seperti itu juga digunakan dengan pertimbangan untuk memudahkan dalam pengontrolan dan pengawasannya.

Pemberian ruang gerak atau kesempatan kepada umat beragama rupanya berefek positif terhadap pertumbuhan agama dan umat beragama. Di Inggeris, Jerman dan Prancis merupakan negara-negara yang saat ini warganya banyak yang muallaf (menganut Islam) setiap tahun. Tumbuh dan berkembangnya umat beragama, khususnya Islam di Barat menjadi pertanda, bahwa kebutuhan manusia terhadap dunia spiritual (agama) selalu muncul ke permukaan dan menjadi daya magis yang memikat, walaupun berada di negara sekuler dan di tengah gempuran modernisasi. Pertemuan dua hal yang kelihatan bertolak belakang akan terjadi benturan nilai, sebagaimana sinyalemen Hungtingtone ${ }^{3}$ yang membuat rumusan tentang terjadinya "benturan antar peradaban dalam globalisasi". Ia mensinyalir globalisasi memungkinkan terjadinya benturan, sebagai akibat dari adanya persentuhan dan tarik menarik kepentingan di semua lini kehidupan manusia, termasuk agama. Pandangan tersebut terdapat perbedaan dengan yang

${ }^{1}$ Safriadi. 2008. Keikutsertaan Masyarakat dalam membangun Kualitas Pelayanan Publik. Blog di WordPress Tahun 2008, h. 1

${ }^{2}$ William Daviddow H. \& Bra Uttal. Total Custumers Service the Ultimate Weapon. , New York: The Free Press . 1989. h. 19

${ }^{3}$ Huntington, Samuel P. "Benturan Antar Peradaban dan Masa Depan Politik Dunia. Yogyakarta: Qalam, 2005, 
dikemukakan oleh John Naisbitt ${ }^{4}$ dalam bukunya Global Paradox. Ia melihat adanya tindakan dan sifat yang "Paradox" di dalam dunia global, terutama bagi kelompok agama minoritas. Di dalam dunia Globalisasi justru semakin memberi peluang bagi munculnya kelompok-kelompok kecil, kesukuan yang berfikir lokal tetapi mengarah kepada tindakan-tindakan global. Sebenarnya itulah yang menjadi modal sosial dan kultural dan sekaligus menunjukkan identitas diri untuk memperjelas eksistensinya. Hal ini bisa dilihat pada berbagai komunitas atau kelompok-kelompok yang ada di perkotaan atau kota-kota besar, banyak terbentuk paguyuban-paguyuban sebagai perwujudan dari suatu tuntutan identitas.

Komunitas muslim Indonesia di United Kingdom menjadi salah satu bukti, kelompok paguyuban yang dibentuk oleh mereka adalah suatu perwujudan keinginan untuk merajut kerinduan berkumpul, disamping mengokohkan penguatan identitas sebagai warga negara Indonesia yang sedang berada di perantauan. Selain itu juga untuk memenuhi kebutuhan spiritual mereka, karena ada pelayanan dalam bentuk kegiatan keagamaan dari para pengurus paguyuban.

Berdasar pada gambaran di atas, menarik melakukan penelusuranterhadap komunitas muslim Indonesia yang ada di Inggeris terkait dengan penyelenggaraan pendidikan keagamaan sebagai pemenuhan tuntutan identitas keberIslaman. Tentu implementasinya tidak terlepas dari kebijakan pemerintah Kerajaan Inggeris (UK) terhadap agama dan umat beragama, secara khusus terhadap penyelenggaraan

${ }^{4}$ Naisbit, John. Global Paradox. London: Nicholas Brealy Publishing, 1988. pendidikan agama dan pendidikan keagamaan

Kehadiran berbagai suku bangsa, terutama dari negara- negara Islam, seperti dari Timur, Tengah, Afrika, dan Asia di Negara Barat dari tahun ke tahun semakin meningkat. Motivasi kehadirannya berbedabeda, ada karena tugas kenegaraan, ada yang datang karena pendidikan, ada juga karena tuntutan pemenuhan kehidupan atau pekerjaan, dan ada yang memang karena pindah tempat tinggal dan pindah kewarganegaraan (imigran), terakhir karena dampak "perang" yang berkepanjangan. Kehadiran mereka di sana dipersatukan oleh identitas "KeIslaman" dan membentuk komunitas tersendiri yaitu komunitas "Muslim." Hanya belum diketahui persis bagaimana mereka memobilisasi diri sebagai warga yang berbeda dengan penduduk asli atau sebagai komunitas yang minoritas mengimplementasikan pendidikan agama dan keagamaan di negara yang sekuler seperti Inggeris.

Warga Negara Indonesia sebagai salah satu bagian dari mereka mencoba mengembangkan kreativitas dengan membentuk kelompok paguyuban dan melakukan beberapa kegiatan keagamaan, salah satu diantaranya adalah pendidikan kagamaan. orang Indonesia di london terhadap tradisi Islam moderat mereka dipindahkan dari negara asal dikontekstualisasikan dengan tradisi keagamaan multikultural diaspora muslim. ${ }^{5}$ Apa dan bagaimana implementasi program pendidikan keagamaan yang dilakukan

${ }^{5}$ Amika Wardana, 2013. Living in Between: The Multiple Integration Trajectories of The London Indonesian Muslim Imigrants. Departemen of Sociology. University of Essex. 
oleh warga negara Indonesia di Inggeris, hingga saat ini belum diketahui secara jelas. Sehubungan dengan itu pertanyaan yang mendasar adalah "Bagaimana Implementasi Pendidikan Keagamaan pada Komunitas Muslim Indonesia di United Kingdom? “

Dari problem ini dimunculkan tiga pertanyaan dasar, yaitu: 1) Seperti apa gambaran kehidupan keagamaan komunitas muslim Indonesia di United Kingdom ?; 2) Bagaiman realitas penyelenggaraan pendidikan keagamaan pada komunitas umat Islam Indonesia di United Kingdom ?; dan 3) Kendala apa saja yang dihadapi, dan bagaimana pemanfaatan faktor-faktor pendukung terselenggaranya pendidikan keagamaan?.

Penelusuran ini dimaksudkan untuk melihat gambaran terselenggaranya pendidikan keagamaan komunitas muslim Indonesia di Inggeris. Secara khusus menjawab pertanyaan di atas, yaitu: a) Mengungkap gambaran kehidupan keagamaan, khususnya komunitas muslim di Indonesia di United Kingdom; b) Mengungkap realitas pemnyelenggaraan pendidikan keagamaan yang dilakukan oleh komunitas muslim Indonesia di United Kingdom; dan c) Mengungkap beberapa kendala yang dihadapi dan cara penangannya, serta bagaimana mengorganisir faktor-faktor pendukung terselenggaranya pendidikan keagamaan bagi komunitas muslim Indonesia.

Penelusuran ini diharapkan bermanfaat pada 2 aspek, yaitu: pertama, masukan awal untuk pengembangan penelusuran lebih lanjut bagi para peneliti dan dosen (akademisi) atau untuk kepentingan keilmuan; kedua, sebagai bahan bandingan dalam mempertimbangkan pengambilan kebijakan, khususnya yang terkait dengan pengembangan pendidikan keagamaan bagi kelompok muslim di luar negeri.

Sejak dari awal persiapan penelitian ini, peneliti mencoba menelusuri tulisantulisan yang terkait sebelumnya, terutama terhadap kajian yang membincang pendidikan keagamaan. Banyak tulisan hasil penelitian yang meneropong implementasi pendidikan keagamaan, misalnya tahun 2007/2008, Fuaduddin TM. dan temanteman dari Puslitbang Pendidikan Agama dan Keagamaan, Badan Litbang dan Diklat Kementerian Agama RI menelusuri persoalan tersebut dan mengangkat di Jurnal Edukasi volume 6 nomor 3 tahun 2008 dengan Topik Pengarusutamaan Pendidikan Keagamaan, kemudian dari topik tersebut masing-masing peneliti menelusuri sesuai obyek dan sasaran masing-masing. Wahid Khosin mengangkat topik "Pendidikan Keagamaan Pada Komunitas Anak Jalanan". Temuannya adalah belum ada bentuk tersendiri dalam mengimplementsikan pendidikankeagamaan pada kelompok anak jalanan. Pendidikan keagamaan yang diberikan berkisar pada siraman rohani (pembinaan mental) terkait dengan persoalan keimanan, dan akhlaq, sambil mereka diajarkan al-qur'an, atau anak jalanan belajar membaca qur'an dan belajar sholat. ${ }^{6}$

Sedangkan penelitian yang lain dilakukan oleh Ta'rifmengangkat "Pelayanan Pendidikan Keagamaan Komunitas Muslim Minoritas di Bali". Ia menemukan, bahwa

${ }^{6}$ Wahid Khosin, Pendidikan Keagamaan Pada Komunitas Anak Jalanan, di dalam "Edukas" jurnal Penelitian Agama dan Keagamaan, volume 6 nomor 3, Juli - September 2008, hal. 44-50 
muncul dan berkembangnya pendidikan keagamaan dari komunitas Islam di Tabanan Bali, karena didasari oleh keinginan memperkuat "identitas keIslaman" di tengah kaum Hindu sebagai mayoritas. Berangkat dari situ sehingga dengan penuh semangat keIslaman mereka menggalang solidaritas dan mengimplementasikannya ke pelayanan pendidikan keagamaan yang dimulai dari TK (Raudhatul Athfal), hingga ke SMA. Demikian halnya pelayanaan pendidikan keagamaan diberikan juga kepada Ibu-Ibu kaum hawa melalui Majelis Taklim.?

Penelitian yang serupa juga dilakukan oleh Arifuddin Ismail di Kudus Jawa Tengah, topiknya adalah Majelis Taklim di Perusahaan Non Muslim. Temuannya mirip serupa, yaitu adanya aktualisasi diri dari kaum muslim dan sekaligus penguatan Identitas keberagamaan para pekerja di Perusahaan non Muslim tersebut. Jadi tampaknya aktualisasi diri dan penguatan identitas dibutuhkan kehadirannya ketika kelompok paguyuban berada pada posisi minoritas, dan dengan penuh semangat mereka akan menggalakkan kegiatan keagamaan dengan variatif. ${ }^{8}$

Mengawali perbincangan ini, perlu menjelaskan terlebih dahulu pengertian "pendidikan agama" dan "pendidikan keagamaan." Pemaknaannya biasa tidak tepat, karena kadang menyamakan antara pendidikan agama dengan pendidikan

${ }^{7}$ Ta'rif. "Pelayanan Pendidikan Keagamaan Komunitas Muslim Minoritas di Bali”. Di dalam Jurnal Edukasi Volume 6 nomor 3Juli-September 2008, hal. 106-123.

${ }^{8}$ Arifuddin Ismail. "Majelis Taklim Hidayatullah di Perusahaan Non Muslim Kudus" di dalam "Jurnal alQalam"Volume 17 Nomor 2.Tuli - Desember 2011 keagamaan, padahal berbeda, akibatnya terdapat kekaburan makna, dan jauh dari makna yang dimaksud. Merujuk pada Peraturan Pemerintah nomor 55 tahun 2007, bahwa:

"Pendidikan agama adalah pendidikan yang memberikan pengetahuan dan membentuk sikap, kepribadian, dan keterampilan peserta didik dalam mengamalkan ajaran agamanya, yang dilaksanakan sekurang-kurangnya melalui mata pelajaran/kuliah pada semuajalur,jenjang, dan jenis pendidikan. Pendidikan keagamaan adalah pendidikan yang mempersiapkan peserta didik untuk dapat menjalankan peranan yang menuntut penguasaan pengetahuan tentang ajaran agama dan/atau menjadi ahli ilmu agama dan mengamalkan ajaran agamanya."

Rumusan pengertian dalam peraturan pemerintah tersebut jelas menunjukkan adanya perbedaan, pendidikan agama dituangkan dalam kurikulum dan pembelajaran yang secara rutin dilakukan. Memang tidak disebut secara terangterangan, tetapi maknanya bisa ditangkap, biasanya penggarisan seperti itu terdapat di dalam satuan pendidikan atau sekolah formal, mulai dari tingkat dasar atau Sekolah Dasar (SD), Sekolah Menengah Pertama (SMP), Sekolah Menengah Atas (SMA) dan Perguruan Tingi. Sedangkan pengertian Pendidikan Keagamaan dari peraturan pemerintah tersebut diphami secara luas bahwa penyelenggaraannya dilakukan di luar Satuan Pendidikan atau sekolah formal.Dalam suatu uraian Wahid Khosin menyebut, bahwa "pendidikan keagamaan bertujuan untuk membentuk peserta didik

${ }^{9}$ Diambil dari Internet, sosialisasi Peraturan Pemerintah nomor 55 tahun 2007 tentang Pendidikan Agama dan Pendidikan Keagamaan 
yang memahami dan mengamalkan nilainilai ajaran agamanya dan atau menjadi ahli ilmu agama yang berwawasan luas, kritis, kreatif, inovatif dan dinamis dalam rangka mencerdaskan kehidupan bangsa yang beriman, bertakwa dan berakhlak mulia." ${ }^{10}$ Selanjutnya menurut Wahid Khozin, pendidikan agama diberikan sebagai upaya membina ketakwaan peserta didik yang mampu merefleksikan sikap dan tindak ketakwaannya dalam semua aspek kehidupan. ${ }^{11}$

Mencermati pemaknaan tersebut bisa dikembangkan ke arah yang lebih specifik bahwa pendidikan agama penekanannya terletak pada pembelajaran yang bersifat doktrinal, baik pada aspek kognitif maupun pada aspek afektivie yang mengarah pada pembentukan attitude. Hal ini merujuk pada watak dasar dari pembelajaran di sekolah formal, kecuali di Perguruan Tinggi. Sedangkan pendidikan keagamaan lebih pada pengembangan penguasaan ilmu pengetahuan atau yang bersifat keilmuan atau scientice, tentu dalam koridor kognitif, dan afektive yang bernuansa plus. Khusus pada aspek ini, sudah tidak ada batas ruang dan waktu belajar, karena berada pada zona pendalaman ilmu keagamaan.

Sebenarnya pendidikan keagamaan lebih bersesuaian jika dikategorikan sebagai pendidikan luar sekolah. PHILIPS H. COMBS, mengungkapkan bahwa "pendidikan luar sekolah adalah setiap kegiatan pendidikan yang terorganisir, diselenggarakan diluar sistem formal, baik

${ }^{10} \mathrm{Op}$. Cit. Wahid Khosin, Pendidikan Keagamaan Pada Komunitas Anak Jalanan, di dalam "Edukas" jurnal Penelitian Agama dan Keagamaan, volume 6 nomor 3, Juli-September 2008, h. 44-50

${ }^{11}$ Ibid. tersendiri maupun merupakan bagian dari suatu kegiatan yang luas, dimaksudkan untuk memberikan layanan kepada sasaran didik dalam rangka tujuan belajar. ${ }^{12}$

\section{METODOLOGI PENELITIAN}

Penelusuran ini sebatas eksplorasi, karena disesuaikan dengan jumlah waktu yang digunakan selama kunjungan, yaitu hanya 7 hari. Keterbatasan waktu dan tenaga, tentu menyesuaikan dengan kondisi sasaran yang dijadikan subjek penelitian, sehingga terasa masih banyak hal yang belum dapat diungkapkan. Faktor inilah yang sekaligus menjadi kekuranan penelitian ini.

Penelitian ini dilakukan di Inggeris/ United Kingdom (UK), dengan memfokuskan diri pada warga negara Indonesia yang saat ini sedang bermukim di Inggeris. Sasaran substansi adalah fokus kepada "penyelenggaraan pendidikan keagamaan oleh warga negara Indonesia di Inggeris (United Kingdom).

Ada dua jenis data yang ditelusuri, yaitu data primer dan data sekunder. Data primer adalah data yang terkait dengan penyelenggaraan pendidikan keagamaan yang didalamnya terdapat data tentang kelompok paguyuban yang menyelenggarakan pendidikan keagamaan, jenis kegiatan, waktu pelaksanaan, peserta atau orang-orang yang terlibat dalam kegiatan tersebut. Demikian halnya peluang penyelenggarakan pendidikan keagamaan, tentu terkait dengan kebijakan umum dari pemerintah setempat. Data primer lainnya yang terkait dengan penyelenggaraan pendidikan keagamaan adalah persoalan

\footnotetext{
${ }^{12}$ http://fstar.hol.es/2014/08
} 
faktor pendukung dan penghambat penyelenggaraan pendidikan keagamaan. Sedang data sekunder dalam penelusuran ini adalah hal yang sifatnya pendukung, termasuk eksistensi Islam dan dinamika Islam di Inggeris, demikian juga gambaran sepintas tentang pendidikan agama di sekolah-sekolah di Inggeris.

Teknik penjaringan data menggunakan: 1) wawancara bebas dan mendalam, terutama kepada para informan kunci, yaitu: pertama, pejabat Kedutaan Besar Republik Indonesia (KBRI) yang berkompeten; kedua, tokoh agama Islam, baik akademisi maupun praktisi keagamaan (pengurus organisasi dan kelompok keagamaan); 2) Observasi, yaitu mengamati langsung kegiatan penyelenggaraan pendidikan keagamaan yang dilakukan oleh komunitas muslim, demikian juga fasilitas pendukung yang digunakan secara langsung maupun tidak langsung.

Terkait dengan kegiatan pengolahan dan analisis data, tentu mengacupada ketentuan-ketentuan yang ada, dan secara metodologis bisa dipertanggungjawabkan. Untuk kepentingan penelusuran ini, menggunakan teknik pengolahan dan analisis "deskriptif kualitatif", sesuai dengan tujuan dan kebutuhan penelitian. Menurut Bernard (1988) di dalam Mudjahirin Thohir ${ }^{13}$ disebutkan bahwaanalisis penelitian kualitatif pada dasarnya menggambarkan dua makna, yaitu sebagai (a) analisis deskriptif dan (b) teori;analisis seperti ini prosesnya ialah dengan menyederhanakan data-data dan menafsirkannya, sehingga

\footnotetext{
${ }^{13}$ Mudjahirin Thohir, "Kehidupan Keagamaan Orang Jawa Pesisir: Studi Orang Islam Bangsri Jepara", Disertasi, Pascasarjana Universitas Indonesiajakarta,2002, h. 28.
}

tertata struktur pemaknaan menurut istilahnya sendiri.

Penggunaan analisis secara kualitatif padapenelitianinimengacupadatigastrategi, sebagaimana juga yang dikemukakan juga oleh Bogdan (1993). ${ }^{14}$ Pertama, Strategi di sini menekankan padaurutan waktu. Data diorganisir berdasarkan kejadian, dan yang terjadi lebih dahulu merupakan antecedent dari yang terjadi kemudian. Jadi, proses terjadinya peristiwa dideskripsikan dengan tetap mengacu secara kronologis pada masalah yang dimunculkan.Kedua, strategi ini memusatkanperhatian pada faktor utama yang menjelaskan timbulnya suatu fenomena berikutnya.Ketiga, Strategi ini memusatkan perhatian pada faktor lingkungan yang dimungkinkan mendorong munculnya suatu fenomena. Secara garis besar, penyajian analisis ini menekankan pada interaksi antarorganisasi atau unsur setting di mana suatu fenomena terjadi. Fokus analisis dibatasi pada hal-hal yang terkait dengan pengelolaan dan pendidikan keagamaan komunitas muslim Indonesia di Inggeris.

\section{HASIL DAN PEMBAHASAN}

\section{Seputar Lokasi Penelitian}

Pemandangan yang berbeda ketika menginjakkan kaki di Kota London United Kingdom, rumah-rumah di sepanjang perjalanan dari Bandara Hethrow menuju Wisma Indonesia berjejer secara teratur dalam bentuk arsitektur yang seragam satu sama lain bernuansa klasik "Brithaniyah"

${ }^{14}$ Bogdan, Robert dan Steven J. Taylor,Metode Penelitian Kualitatif, Surabaya: Usaha Nasional, 1993, h. 55 . 
(istilah peneliti), membuat taajjub' dan memunculkan pertanyaan: "Mengapa di negara moderen dan sekuler seperti ini masih peduli dengan nuansa klasik tradisional, apakah tidak bertentangan dengan pikiranpikiran kemoderenannya ? Setelah sedikit bergeser ke pusat kota London, ternyata nuansa klasik itu menyebar ke seluruh penjuru kota. Tidak satupun rumah-rumah warga kota London yang tampak berbeda jauh dengan warga lainnya, walaupun itu tergolong bangunan bertingkat. Perasaan mulai menggoda pikiran, ada sesuatu di hati peneliti seakan hidup di dunia lain yang berbeda $100 \%$ dengan kebiasaan hidup di semua kota besar Indonesia.

Pada saat observasi sedang berjalan sambil membangun dialog dan diskusi dengan beberapa orang, maka kesimpulan sementara yang bisa diambil adalah ternyata orang Inggeris maju dalam kemoderenan, karena beberapa aspek, yaitu "disiplin,taat pada aturan yang ada, atau dengan kata lain orang Inggeris suka Keteraturan". Demikian juga pemerintah Kerajaan Inggeris memiliki komitmen dan konsistensi secara ketat dalam penegakan aturan, sehingga warga Inggeris terbawa dengan sistem yang ada, semua warga pribumi maupun non pribumi tunduk dan taat kepada aturan yang diberlakukan.

Rumah-rumah tertata secara apik begitu, karena ada aturan yang mengikat kepada semua warga Inggeris, salah satunya adalah "dilarang merubah (menambah/ mengurangi) setiap bangunan yang ada, terutama rumah-rumah dan kantorkantor, apalagi melakukan perubahan jauh dari bentuk aslinya. Aturan tersebut diikuti dengan pemberian sanksi secara ketat kepada siapa saja yang melakukan pelanggaran. Barangsiapa yang melakukan pelanggaran, maka sanksi yang diberikan adalah mengembalikan bangunan itu kepada bentuk aslinya. Inilah yang dihindari warga, karena rupanya biaya pengembalian kepada bentuk semula akan lebih mahal lagi.

Sepintas tentang United Kingdom (UK) sebagai wilayah kerja penelitian, terbagi ke dalam 4 wilayah : England, Scotland, Wales, dan Nothern Ireland. Keempat wilayah ini merupakan wilayah yang memiliki otonomi, khususnya di dalam pengaturan pemerintahan. Di dataran Inggeris dalam hal ini yang populer di Eropa adalah United Kingdom atau biasa disingkat dengan sebutan "UK", sebutan lain yang populer sebagai Britania Raya, atau Inggris Raya, adalah suatu negara berdaulat yang terletak di lepas pantai baratlaut benua Eropa. Britania Raya adalah sebuah negara kepulauan yang terdiri dariPulau Britania Raya, bagian timur laut Pulau Irlandia dan sejumlah pulau-pulau yang lebih kecil. Irlandia Utara adalah satu-satunya bagian dari Britania Raya yang berbagi perbatasan darat dengan negara berdaulat lain, yaitu Republik Irlandia. Selebihnya, perbatasan darat Britania Raya dikelilingi oleh Samudera Atlantik, Laut Utara, Selat Inggris dan Laut Irlandia.

Dari sisi pemerintahan Britania Raya adalah sebuah negara kesatuan yang diatur di bawah monarki konstitusional dan sistem parlementer, dengankursipemerintahannya berada di ibu kota London. Inggeris (Britania Raya) tidak menggunakan istilah provinsi sebagaiamana di Indonesia, tetapi yang ada negara bagian. Terdapat empat negara dalam kedaulatan Britania Raya yang masingmasingnya berdiri sendiri. Inggris (england), skotlandia, Wales, dan Irlandia Utara. 
England memiliki 32 kecamatan, Skotlandia 32 Kecamatan, Wales 10 kecamatan, dan Irlandia Utara memiliki 11 Kecamatan. ${ }^{15}$

Selain England, tiga negara yang disebut terakhir memiliki pemerintahan tersendiri yang berbeda-beda kekuasaannya, dan berpusat di ibu kota masing-masing, yaitu Irlandia Utara dengan Ibu Kotanya Belfast, Skotlandia dengan Ibu Kotanya Edinburgh, dan Wales dengan Ibu Kotanya Cardiff. Britania Raya juga memiliki tiga wilayah Dependensi Mahkota, yakni Guernsey, Jersey, dan Pulau Man. Wilayah-wilayah tersebut terkait, namun secara konstitusional bukanlah bagian dari Britania Raya. Selain itu, terdapat empat belas wilayah seberang laut Britania. Wilayah-wilayah tersebut merupakan sisasisa dari Imperium Britania, yang pada suatu masa pernah menjadi imperium terbesar di dunia yang meliputi hampir seperempat luas total bumi. Pengaruh Britania Raya (khususnya Inggris) bisa dijumpai di negara-negara bekas koloninya dalam hal penggunaan bahasa, sistem hukum, sistem pemerintahan, dan budaya.

Britania Raya adalah salah satu negara maju dengan ekonomi terbesar keenam di dunia menurut PDB nominal dan terbesar kedelapan di dunia menurut keseimbangan kemampuan berbelanja. Britania Raya juga merupakan negara industri pertama di dunia, dan menjadi penguasa dunia pada abad ke-19 dan awal abad ke-20. Hingga saat ini, Britania Raya telah menjadi negara yang memiliki kekuatan besar (super power bersama dengan USA, Rusia, Perancis dan Cina). Pengaruh Britania Raya juga sangat

${ }^{15}$ Disadur dari https://en.wikipedia.org/wiki/ Countries_of_United_Kingdom besar dalam berbagai bidang, secara khusus di bidang ekonomi, budaya, sains, politik dan juga militer.

Britania Raya diakui sebagai negara yang memiliki senjata nuklir, dan pengeluaran militernya menempati urutan terbesar keempat di dunia. Britania Raya adalah anggota tetap Dewan Keamanan PBB sejak tahun 1946 dan telah menjadi anggota Uni Eropa serta pendahulunya; Masyarakat Ekonomi Eropa, sejak tahun 1973. Britania Raya juga merupakan anggota NegaraNegara Persemakmuran, Majelis Eropa, G7, G8, G20, NATO, OECD, dan Organisasi Perdagangan Dunia (WTO).

\section{Fenomena Kehidupan Keagamaan: Suatu Tuntutan Penyesuaian Yang Longgar}

Sebelum tahun 1950, Q. William, seorang warga negara Inggeris yang berdomisili di Liverpool menyatakan diri memeluk Islam. Konversi agama ini menghebohkan Inggeris saat itu, karena penganut Nasrani masih sangat kuat pengaruhnya dalam kehidupan masyarakat. Kejadian terebut juga kedengarannya langka, bahkan Q. William ini dikenal sebagai pemeluk Islam yang kontroversial di Inggeris, kemudian disusul yang lain dan hingga saat ini satupersatu orang-orang Inggeris berpindah agama ke Muslim.

Bahkan beberapa di antara mereka diketahui telah mencoba mempelajari berbagai agama, sebelum beralih ke Islam, misalnya belajar tentang Yahudi, Prostestan, Hindu, kemudian belajar tentang Islam. Justru setelah mereka mempelajari Islam, ada daya tarik tersendiri yang dirasakan berbeda, makanya mereka memilih Islam sebagai agama mereka. Jadi di samping 
penduduk asli Inggeris yang satu persatu memeluk Islam, berbarengan dengan munculnya para pendatang baru di Inggeris dan sudah menetap di Inggeris.

Umat Islam mulai establish di Inggeris sekitar 70 tahun yang lalu, yaitu sekitar tahun 1950-an, ketika Inggeris membutuhkan tenaga kerja yang dianggap murah. Didatangkanlah orang-orang Pakistan, India, Iran, Afganistan, Sri Langka dan Banglades menjadi tenaga kerja di pabrik-pabrik Tekstil dan Industri lainnya, di kawasan Brimingham, Manchester dan sebagainya.

Kehadiran mereka ternyatabukan hanya sebatas sebagai tenaga kerja, tetapi karena keluarga mereka juga ikut bermigrasi ke Inggeris, tentu seiring dengan itu muncul tuntutan lain, seperti mengharapkan juga anak-anaknya bisa melanjutkan pendidikan. Setelah putra-putrinya dimasukkan ke sekolah Inggeris, mereka merasa ada sesuatu yang tidak terpenuhi. Kebutuhan pendidikan ini dianggap tidak bisa memenuhi harapannya secara keseluruhan, karena ada beberapa aspek tidak terpenuhi, terutama pendidikan agama.

Kelompok-kelompok

pendatang dari Arab, Pakistan, Banglades India dsb Menganggap pendidikan di Inggeris tidak menjawab seluruh kebutuhan mereka, termasuk pendidikan agama, akhirnya berinisiatif mendirikan sendiri sekolahsekolah yang ada pelajaran agama Islam. Memang sebelumnya di Inggeris sudah terdapat sekolah agama yaitu dari kelompok Katolik, Protestan, dan Yahudi, tetapi itu dianggap tidak sesuai dengan keyakinan mereka sebagai penganut Islam.
Berangkat dari tuntutan tersebut, maka para imigran/pendatang dari negara-negara yang berpenduduk muslim berinisiatif dan bersepakat mendidirikan, masjid, mushollah dan sekolah-sekolah nonformal (madrasah diniyah). Penyelenggaraan pendidikan non formal, awalnya di masjid-masjid dengan memanfaatkan waktu akhir pekan (weakend) untuk membekali anak-anak mereka dengan pendidikan keagamaan. Bahkan ada juga dalam bentuk sekolah formal, seperti madrasah di Indonesia dengan ketentuan mengikuti ketentuan yang berlaku di Inggeris.

Tentu kalau mau mendapatkan subsidi dari Pemerintah harus mengikuti aturanaturan yang berlaku di Inggeris. Misalnya di suatu sekolah harus menggunakan pengantar dalam bahasa Inggeris, atau kurikulumnya minimal berdasar pada apa yang diberlakukan di Inggeris. Standarisasi sekolah-sekolah itu menjadi kewajiban yang harus dipenuhi oleh sekolah, baik yang didirikan oleh para pendatang maupun sekolah-sekolah yang berdiri di seantero United Kingdom. Kalau ada sekolah yang tidak berdasar pada ketentuan pemerintah, maka akibatnya tentu diberlakukan suatu sanksi terhadap sekolah yang melakukan pelanggaran.

Pada sekitar tahun 1970-an seorang yang berkebangsaan dan warga negara Inggeris mengagetkan banyak orang, di tengah orang-orang Inggeris yang seakan berada di pesimpangan jalan, dengan keyakinan agama yang tidak jelas, bahkan sudah sangat sekuler. Mereka tidak menemukan banyak jawaban dari kemoderenan yang dijalani selama ini, dan dari agama yang diyakini sebelumnya. Tiba-tiba ada seorang warga negara asli Inggeris menyatakan 
diri memeluk Islam. Namanya "Cat Steven" kemudian setelah memluk Islam menggunakan "Muhamad Yusuf". Beliau seorang seniman musik dan memiliki Group Band pada tahun 1970, beliau inilah yang mendirikan sekolah yang berlabel "Islam" pertama di London Inggeris.

Pemerintah Inggeris memperbolehkan saja, tanpa ada halangan sedikitpun, sehingga pengelola sekolah juga merasa leluasa dan merasa nyaman melakoninya. Pemerintah Inggeris sendiri merasa terusik, dan baru agak merasa perlu melihat sekolah-sekolah atau lembaga pendidikan yang berbasis Islam, ketika terjadi kritik atau tuduhan bahwa lembaga seperti itu menjadi tempat munculnya radikalisme. Mulai saat itu pemerintah Inggeris merasa berkewajiban untuk mengetahui kondisi sebenarnya tentang Islam di Inggeris. Pemerintah Inggeris melakukan intaian terhadap Islam dan berbagai kegiatan keislaman, termasuk di masjid-masjid. Agar supaya kontrolnya bisa diobservasi secara jelas, maka harus bisa dipahami melalui komunikasi yang digunakan, yaitu bahasa Inggeris. Dibuatkanlah suatu aturan bahwa Imam-Imam dan pengajar harus bisa berbahasa Inggeris dan menyampaikan dakwahnya dalam bahasa Inggeris. Sekolahsekolah sebaiknya mengikuti standar yang dicanangkan pemerintah Inggeris, terutama pada kurikulum yang diberlakukan.

Sementara itu masjid-masjid di Inggeris juga memiliki kegiatan yang variatif, yaitu: Pertama: Ada kegiatan yang memberi pelayanan umat 1 kali 24 jam, sebagaimana halnya masjid Islamic Iinggeris Centre Mausque. Kegiatan di masjid ini cukup padat, dalam satu minggu jadwal sudah tersusun rapi, terutama untuk kegiatan pendalam Islam.
Mulai dari pengajian baca tulis al-quran, pengajian tafsir dan hadits, seminar-seminar dan kursus-kursus tentang tentang Islam. Bagi peserta yang ikut dalam kegiatankegiatan tersebut diberi kemudahan baik pembiayaan, peserta tidak dipungut biaya (free).

Guna memudahkan komunikasi dan informasi terutama dalam pemberian informasi yang lebih luas, maka pengurus ICCUK membuatkan website tersendiri www. iccuk.org untuk mensosialisasikan Islam dan juga program kegiatan ICCUK. Demikian juga pengurus membuatkan mail tersendiri untuk memudahkan pendaftaran bagi yang ikut dalam kegiatan tersebut, yaitu: interfaith@icuk.org. Informasi terkait dengan kegiatan di Islamic Centre United Kingdom (ICUK) dapat dilihat di media sosial dan juga di masjid ICCUK melalui papan informati elektric yang dipasang secara paten di samping perpustakaan, dan di pintu masuk masjid.

Kegiatan-kegiatan tersebut bisa dilakukan karena didukung oleh Para pengurus masjid yang memang memiliki komitmen keIslaman yang kuat, punya visi yang sangat progresif, memberi fasilitas tempat dan mensuport pembiayaannya. Pengurus masjid juga menyiapkan ruanganruangan dan aula sebagai fasilitas pertemuan nyang lebih besar. Kepengurusan masjid ICCUK juga sudah tertata dengan rapi. Dari sisi struktur juga lengkap, mulai dari para pengurus inti hingga ke tenaga pembersih (cealing servise), demikian juga karyawan lengkap dengan tenaga security.

Salah satu kunci dasar yang menopang program kegiatan ICCUK adalah pengurus ICCUK memiliki sumber-sumber ekonomi, 
seperti Hall/Aula, disewakan untuk berbagai kegiatan, ada toko, restoran, dan sebagainya. Toko dan restoran dibuka dari beberapa menit sebelum subuh sampai sesudah Isya baru tutup, ini dilakukan sebagai salah satu bentuk pelayanan terhadap umat.

Selain dari kegiatan pelayanan yang dilakukan oleh masjid ICCUK, ada juga beberapa masjid yang buka hanya beberapa saat sebelum dan sesudah sholat fardhu. Masjid- masjid lainnya juga memberi pelayanan, tetapi hanya pelayanan ibadah. Bisa dimaklumi karena karena rata-rata pengelola masjid memiliki pekerjaan sendiri-sendiri. Type masjid seperti ini, biasanya dalam bentuk mushollah seperti di Indonesia, kapasitasnya lebih kecil, digunakan sekedar untuk sholat jama'ah fardhu.

Ukuran masjid tidak terlalu besar, boleh disebut ukuran sedang, karena memuat sampai 100 orang jamaah. Hanya setiap masjid dilengkapi dengan fasilitas, seperti toilet, tempat wudhu dan perpustakaan yang berukuran kecil. Di daerah London Brich dan Regen Park rata-rata masjid di sini bertingkat, kondisinya berada di tengah rumah toko yang memang memiliki konstruksi bertingkat. Tapi untuk pelayanan keagamaan, khususnya pelaksanaan sholat 5 (lima) waktu, ketersediaan masjid seperti itu cukup membantu dan dianggap cukup memadai dan kapabel sebagai sebuah tempat ibadah.

Menurut Abdul Karim Awad, masjid memiliki peran penting dalam pengembangan masyarakat Islam di London. Masjid berfungsi sebagai tempat pencerahan spiritual, penguatan isu persatuan dan inklusi antar komunitas, penguatan isu keadilan sosial, media informasi, sebagai tempat pembelajaran agama, dakwah, pengadilan (agama), tempat pelayanan kesehatan, bank makanan, tempat umat Islam melakukan festival, tempat pelayanan muallaf, dan tempat pengembangan dialog antar iman. ${ }^{16}$

Warga Negara Indonesia di United Kingdom, tersebar di beberapa tempat, dan kebanyakan tinggal di London, dan sekitarnya, termasuk di Liverpool, Wimbledone, Brimingham, bahkan hingga ke Calchster. Orang-orang Indonesia tidak merasa susah dengan kondisi yang ada, mereka bisa menyesuaikan diri terhadap kondisi itu, karena di samping didukung oleh ketatnya aturan kedamaian, dalam arti ada aturan yang tidak memperbolehkan kepada setiap penduduk untuk tidak melakukan keonaran, atau kekacauan, sebaliknya harus menciptakan kedamaian di tengah warga. Menjadikan warga negara Indonesia merasa nyaman, tanpa harus merasa was-was, karena siapapun yang melakukan pelanggaran maka dirinya akan diproses sesuai aturan yang berlaku.

\section{Penyelenggaraan Pendidikan Keagamaan}

\section{Lembaga Penyelenggara Pendidikan Keagamaan}

Lembaga pendidikan yang menangani pendidikan agama secara formal di United Kingdom belum eksis, sebagaimana yang ada di negara-negara yang berpenduduk mayoritasmuslim, salahsatunyadiIndonesia. Ada lembaga pendidikan yang didirikan oleh Muhamad Yusuf, yaitu "Islamic Collage"

${ }^{16}$ Abdul Karim Awad. 2015.The Role of The Mosque $21^{\text {st }}$ Century Britain. Message of Islam: UK., h. 104-111. 
(Sekolah Islam), seperti yang telah diungkap terlebih dahulu, tetapi hanya sebatas label, sekolahnya mengelola pendidikan umum, seperti halnya di Indonesia yang dikelola oleh "yayasan" yang berinisial nama Islam, seperti "Al-Azhar", "Mumtaz", "Athirah", "Al-Biruni" at-Thifyan, dan sebagainya.

Terkait dengan itu, orang tua yang berlatar belakang muslim merasa punya kebutuhan lain yang belum terpenuhi, yaitu kebutuhan di bidang keagamaan. Mereka punya rasa tanggung jawab yang besar terhadap pendidikan putra-putrinya, oleh karena itu mereka melakukan cara masing-masing untuk memberi pelajaran tambahan berupa pendidikan agama. Bagi orang tua yang memiliki dasar pengetahuan agama yang cukup, maka secara langsung mengajarkan dan membimbing putraputrinya di rumah saat kembali dari sekolah, ada juga yang menggunakan jasa dari para pelajar/mahasiswa Indonesia yang sedang melanjutkan pendidikannya di United Kingdom, dan memiliki pemngetahuan agama. Bahkan ada yang sangat aktif mengikutkan putra-putrinya pada pengajian-pengajian yang diselenggarakan oleh perkumpulan atau paguyuban tertentu.

Kelompok Muslim Indonesia yang tinggal di UnitedKingdom memilikibeberapa perkumpulan yang menyelenggarakan pendidikan keagamaan dalam bentuk "pengajian",yaitu: 1) al-Ikhlas; 2) KBRI; 3) Indonesia Islam Centre (IIC); 4) KIBAR (Keluarga Indonesia Muslim di Britania Raya) UK; 5) PC. Istemewa NU Inggeris; 6) PC. Istimewa Muhammadiyah Inggeris. Di antara 6 kelompok paguyuban di atas, kelompok paguyuban KBRI yang paling tua, yaitu didirikan sekitar tahun 1960-an dan hingga saat ini berlangsung.
IIC banyak dari kalangan Tenaga Kerja Indonesia (TIKI). beberapa kelompok pengajian: 1. al-Ikhlas, ketuanya Muh. Ikbal Mahasiswa S3 di Impereial University, jurusan Fisika ; 2. KBRI, ketuanya Jamalullail; dan 3. Indonesia Islam Centre (IIC), pembinanya ; 4. KIBAR (Keluarga Indonesia Muslim di Britania Raya) UK. Ketuanya Muh. Rifki. Kelompok keempat ini adalah perhimpunan umat Islam Indonesia di seluruh United Kingdom (UK). IIC banyak dari kalangan Tenaga Kerja Indonesia (TIKI)

\section{Kegiatan Pendidikan Keagamaan}

Pendidikan agama di United Kingdom (UK), sangat berbeda dengan yang dilakukan di Indonesia. Semua sekolah formal memang memasukkan pelajaran agama sebagai salah satu mata pelajaran, tetapi konsep pembelejarannya berbeda. Ada pelajaran agama, tetapi diajarkan secara sincetifik, artinya semua agama diajarkan secara keilmuan tetapi hanya sambil lalu, tidak mendalam. Tidak diajarkan satu persatu, masing-masing agama hanya di ajarkan pokok-pokoknya, misalnya Konsep-konsep Ketuhanan (theology) di semua agama, tanpa pembahasan secara mendalam tentang Tuhan, misalnya Islam itu meyakini adanya Tuhan Yang Esa, dan tidak lagi mengurai seperti eksistensi Tuhan Yang Esa itu, bagaimana perwujudannya, dan sebagainya, demikian juga persoalan yang lain. Kegiatan yang dilakukan di masing-masing lembaga:

Pertama, Di KBRI ada kegiatan bulanan, seperti pengajian dengan pesertanya sekitar 100 orang, terdiri atas orang Indonesia yang sudah mukim (berdomisili di Inggeris), ada juga dari kalangan pekerja wiraswasta, dan pelajar-mahasiswa. Pengisi acara 
kebanyakan dari kalangan mahasiswa Indonesia yang kebetulan melanjutkan pendidikan di Inggeris. Beberapa mahasiswa di Inggeris ada yang berlatarbelakang agama, seperti alumni Pesantren atau sekolah agama. Kadang juga mengundang dari Indonesia, seperti Ustazah Zaitunah Subhan, Ustaz Buchori Muslim, Ustaz Nurul Huda. Waktu kegiatan setiap bulan pada malam sabtu terakhir. Kedua, Biasanya mahasiswa yang tampak fanatik terhadap agama adalah yang berlatar belakang non agama atau dari sekolah jurusan sincetific. Perspektif keagamaannya cenderung lebih ekslusif dibanding dengan yang lain. Mereka itulah yang mensponsori terbentuknya KIBAR dan hingga kini kegiatan-kegiatannya masih berjalan. Ketiga, Di Kibar banyak mahasiswa yang fanatik di KIBAR, makanya minstreamnya berbeda dengan yang lain. Kondisi ini juga sebenarnya membuat banyak juga yangtidak mau ikut di kegiatan KIBAR. Di KIBAR juga sering mendatangkan penceramah atau muballigh dari Indonesia, Seperti Azziraj. Keempat, Umat Islam Indonesia di London cukup banyak, sekitar 1000 orang. Ini perkiraan dengan mengambil dasar pada data yang ada di pencatatan saat PEMILU. Dari data based yang ada. Kelima, Topik yang menjadi Krusial pernah di bahas adalah "ISLAM NUSANTARA" dan mendapatkan reaksi dari peserta tentang itu, jadinya ramai. Hanya Ustaz Nurul Huda memberikan penjelasan yang secara tuntas. Keenam, Di sini juga ada Ustaz yang kencang artinya "Keras" seperti pak Hilal, cucu dari K. H. Ahmad Dahlan. Beliau saat ini menjadi pengacara di London.

\section{Faktor Pendukung Kegiatan Keagamaan}

\section{Mobilisasi Pertemuan}

Salah satu hal yang sulit dihindari oleh orang-orang Indonesia di rantau adalah keinginan untuk berkumpul bersama dengan sesama orang Indonesia. Keinginan tersebut rupanya lahir dari dorongan "rasa rindu terhadap suatu suasana keindonesiaan." Artinya ada suasana di Indonesia yang ingin dirasakan ketika berada di Inggeris. Misalnya, sebelum ke Inggeris, sudah terbiasa kumpul-kumpul bersama temanteman, baik sekantor, seprofesi maupun bersama sanak keluarga. Kebiasaan kumpul itu dilakukan setiap bulan, bahkan ada diantara mereka yang sudah biasa kumpul setiap minggu.

Menurut beberapa orang di antara mereka, bahwa kumpul setiap minggu itu sudah merupakan rutinitas yang dilakoni di Indonesia, kecuali ada kesibukan yang tidak bisa dihindari. Sebenarnya kegiatan kumpul-kumpul itu banyak manfaatnya, disamping silaturrahim dimaksudkan untuk membincang hal-hal yang krusial, dari persoalan keluarga hingga persoalan negara atau situasi negara yang lebih besar. Suasana seperti itulah yang dirindukan di Inggeris atau hiduap di rantau.

Sebenarnya, sekitar tahun 1960-an pemerintah Republik Indonesia yang direpresentasikan oleh Kedutaan Besar Republik Indonesia (KBRI) di United Kingkdom telah mencanangkan pertemuan bulanan secara rutin, bagi warga Indonesia yang tinggal di Inggeris; dan itu berjalan hingga saat ini. Mobilisasi pertemuan tersebut dimaksudkan disamping sebagai ajang silaturrahim juga untuk mendekatkan orang-orang Indonesia 
dengan pemerintahnya, sehingga bisa terbangun komunikasi diantara mereka. Juga dimaksudkan untuk ajang sosialisasi program-program pemerintah Indonesia, khususnya yang terkait dengan kebijakan pelayanan warga negara di luar negeri.

Dalam pertemuan bulanan di KBRI biasanya dihadiri oleh sekitar 100 orang lebih, terdiri atas: 1) para warga negera Indonesia yang bekerja atau punya usaha sendiri di Inggeris (wiraswastawan); 2) warga negara yang menjadi pegawai baik di KBRI maupun di perusahaan swasta; 3) warga negara Indonesia yang melanjutkan studinya di Inggeris, baik yang mengikuti S2 maupun yang mengikuti program S3.

Awalnya pertemuan tersebut hanya dirancang untuk sekedar pertemuan silaturrahim secara rutin untuk mendekatkan pemerintah kepada warganya yang ada di Inggeris, namun perkembangan selanjutnya diisi oleh ceramah-ceramah umum dan pengajian agama. Ini dimaksudkan sebagai salah satu bentuk rangsangan yang diharapkan bisa menggugah warga Indonesia untuk selalu hadir pada pertemuan bulanan.

Selain pertemuan rutin di KBRI, kelompok muslim Indonesia Inggeris juga melakukan hal yang sama, hingga membentuk paguyuban yang diberi nama Indonesia Islamic Centre (IIC). Mobilisasi pertemuan di paguyuban ini malah lebih intensif dibanding dengan yang dilakukan oleh KBRI, karena pertemuan yang digalakkan melibatkan keluarga dalam hal ini anak-anak (putra-putrinya). Kemudian kegiatannya juga lebih variatif, karena paguyuban ini juga membentuk majelis taklim khusus ibu-bu atau kaum hawa (perempuan).

Demikian juga dengan kelompok organisasi sosial keagamaan, seperti Pengusur Nahdlatul Ulama (NU) Cabang IstimewaInggeris, Pengurus Muhammadiyah Cabang Istimewa Inggeris, dan juga kempok pengajian al-Ihsan yang dibentuk oleh para akademisi yang kebetulan melanjutkan studi di Inggeris. Ketiga kelompok paguyuban yang disebut terakhir semuanya merancang mobilisasi pertemuan bulanan dengan muatan pendidikan keagamaan non formal; dan ini sekaligus merupakan potensi yang bisa memberi kontribusi terhadap pengembangan pendidikan keagamaan.

\section{Kegelisahan Pemenuhan Kebutuhan}

Tidak bisa dipungkiri bahwa Warga negara Indonesia yang ada di Inggeris saat ini merasa senang tinggal atau berada di Inggeris, karena suasana kehidupan yang sedikit berbeda ketika berada di Indonesia. Akan tetapi ada sisi-sisi kehidupan sosial kemasyarakatan yang tidak ditemukan di Indonesia, tetapi didapatkan di Inggeris, begitu juga pada aspek-aspek yang lain, terdapat perbedaan.

Namun demikian ada sesuatu yang menggelisahkan dan memprihatinkan, secara khusus pemenuhan aspek kerohanian bagi putra-putri mereka melalui pendidikan agama. Keprihatinan itu wajar dan tidak berlebih jika itu dimunculkan sebgai suatau kebutuhan yang prioritas. Kebutuhan tersebut dianggap sangat penting, karena di sekolah-sekolah Inggeris tidak didapatkan. Sekolah-sekolah di Inggeris memiliki kurikulum tersendiri, dan materi agama diajarkan secara 
kolektif, artinya pembelajaran agama yang menyeluruh untuk semua agama. Sistem pembelajarannya juga dilakukan dengan ciri sifat keilmuan, bukan bersifat doktrinal, sebagaimana halnya di Indonesia.

Kegelisahan untuk pemenuhan kerohanian dirasakan oleh orang tua murid, terutama yang berlatar balakang muslim. Semua informan yang ditemui memunculkan permasalahan yang serupa, merasakhawatir, jangan sampai putraputrinya tidak memahami lagi ajaran agamanya. Berangkat dari kegelisahan seperti itu, sehingga terpanggil untuk bergabung dengan paguyuban kelompok pengajian yang ada. Walaupun pada paguyuban kelompok keagamaan itu hanya menyajikan model pendidikan nonformal, tetapi sedikit-banyaknya bisa menambah pengetahuan, skill dan sekalgius ilmu pengetahuan (scientis). Situasi seperti inilah yang dianggap sebagai suatu potensi pendukung yang bisa melanggengkan kegiatan paguyuban, khususnya pelayanan keagamaan bagi para anggotanya. Di dalamnya terdapat suatu motivasi sebagai pendorong. Jadi, dari aspek psychologinya, kegelisahan itu menjadi potensi pendukung untuk menghadirkan sesuatu yang bernilai bagi dirinya dan bagi puta-putrinya.

\section{Sarana Tempat Pertemuan}

Setiap penyelenggaraan suatu even memerlukan tempat sebagai sarana pendukung, terlepas dari bentuk dan modelnya, begitu juga dari sisi status kepemilikan, apakah itu sewa, pinjam atau milik sendiri. Suatu tempat kegiatan menjadi hal penting dan menentukan terselenggaranya kegiatan. Bagi kelompok- kelompok paguyuban yang dibentuk oleh masyarakat Indonesia di Inggeris, khususnya komunitas muslim, ada yang memang sudah memiliki tempat permanen dan ada yang mengambil tempat di rumah-rumah anggota secera bergilir.

Khusus kegiatan yang dikordinir oleh KBRI tentu tidak mempermasalahkan "tempat", karena menggunakan aula yang terdapat di gedung KBRI. Aula gedung KBRI juga dilengkapi dengan fasilitas yang lengkap, termasuk kursi, meja, AC, penerangan lampu, peralatan sound system, dan peralatan presentase. Aula ini memiliki daya tampung hingga 150 orang. Di sinilah kegiatan-kegiatan pertemuan bulanan dalam hal ini pengajian atau ceramah agama dilangsungkan.

Sementara itu, kelompok paguyuban yang terhimpun dalam "Indonesia Islamic Centre" (IIC) juga merasa terbantu dengan adanya tempat sekretariat yang sudah menjadi milik IIC. Tempat sekretariat IIC tersebut adalah sebuah rumah yang terletak di daerah "Colindale", suatu daerah kawasan perumahan para pejuang dari milisi Angkatan Udara Inggeris.Rumah ini sebelumnya adalah milik seorang warga negara Indonesia yang dihibahkan ke pengurus Indonesia Islamic Centre untuk dijadikan "pusat kegiatan".

Posisi tempat pusat kegiatan IIC ini cukup strategis, karena terletak di depan jalan yang cukup lebar. Bangunannya masih terbilang sederhana, karena masih dalam bentuk rumah, ukurannya terbilang kecil sekitar 8 X 15 m, namun memiliki arsitektur Britaniyah klasik. Pada bagian bawah (lantai 1 ) digunakan untuk ruang pertemuan yang bisa memuat 30 sampai 40 
orang, sedangkan lantai 2 dijadikan ruang kerja pengurus dan kamar tidur staf yang tinggal di sekretariat. Gedung sekretariat IIC ini sudah bisa dimanfaatkan menjadi pusat pengelolaan kegiatan organisasi, khususnya untuk kegiatan pelayanan dan pemenuhan kebutuhan anggotanya.

Sebenarnya sudah ada keinginan dari Pengurus IIC untuk melakukan pembangunan Gedung IIC yang lebih representatif, namun masih belum terwujud, karena masih berbeda pandangan. Ada yang menghendaki membangun yang baru dan lebih bear, berdaya tampung $150-200$, di sekitarnya ada ruangan yang bisa digunakan untuk kepentingan yang lain, tapi dengan catatan gedung yang ada sekarang dijual. Hanya, ini tidak bisa dilakukan karena gedung tersebut adalah hibah "wakaf" yang tidak bisa diperjualbelikan. Pada sisi yang lain ada juga yang menghendaki untuk membangun "sekolah Indonesia", tentu kalau dibanding dengan yang sudah ada harapannya jauh lebih besar, karena berharap didalamnya ada bangun sekolah yang didukung beberapa fasilitas sarana dan prasarana. Semua keinginan itu baru sebatas keinginan, karena belum tampak tanda-tanda untuk "action", sehingga gedung lama masih digunakan sebagaimana apa adanya.

Sementara kelompok paguyuban yang lain, belum memiliki tempat sebagai pusat sekretariat dan pusat kegiatan organisasi. Tempat sekretariat, masih menumpang sementara di rumah ketua masing-masing. Demikian halnya penyelenggraan kegiatan, masih dari rumah ke rumah secara bergilir. Jadi dari rumah pengurus itulah dimobilisasi semua kegiatan organisasi. Tentu kondisi ini mempengaruhi dinamika kegiatan, baik dari sisi variasi kegiatan, frekuensi kegiatannya, kuantitas, dan maupun kualitasnya.

\section{Kendala Yang Dihadapi}

Kegiatan penyelenggaraan pendidiikan keagamaan yang dimotori oleh kelompokkelompok paguyuban di Inggeris, masih berjalan apa adanya, artinya masih dilakukan secara sederhana. Belum dirancang ke arah sistem pembelajaran yang Ideal, dalamarti sistem yang ada didalamnya belum terdapat kurikulum yang tersusun rapi. Waktu penyelenggaraan masih terbatas pada pertemuan $1 \mathrm{X}$ sebulan. Padahal kalau dibandingkan dengan kegiatan yang diselenggarakan oleh Islamic Centre United Kingdom (ICUK), sangat berbeda jauh. Beberapa faktor yang menjadi kendala adalah:

Pertama, Warga negara Indonesia di United Kingom jumlahnya sudah cukup besar dan tersebar dibeberapa negara bagian atau propinsi. Jarak dari pusat kota London dengan provinsi provinsi lain sebenarnya tidak begitu jauh, hanya cukup menyita waktu, sehingga membuat sebagian warga agak malas mengikuti pertemuan bulanan tersebut.

Kedua, Kesibukan masing-masing warga yang memiliki pekerjaan rutin di kantor atau di tempat kerja bagi wiraswastawan, begitupula bagi mahasiswa yang sedang sibuk dengan tugas-tugas dari kampus dimana mereka melanjutkan pendidikannya, sehingga waktu untuk menghadiri kegiatan di kelompok paguyubannya tidak bisa terpenuhi.

Ketiga, Belum ada satu wadah yang bisa menghimpun warga negara Indonesia, yang secara khusus memberikan pelayanan 
pendidikan agama secara formal melalui "sekolah Indonesia", sebagaimana yang terdapat di negara-negara lain.

\section{Beberapa Alternatif Pilihan Masa Depan}

\section{Rekayasa Dakwah Islam}

Belajar dari beberapa realitas dakwah di masjid-masjid danjuga dibeberapa kelompok paguyuban masyarakat di London, dan Leichester, United Kingdom, menunjukkan bahwa dakwah Islamiyah tampaknya sangat dinamis dan menggairahkan. Para pengurus di beberapa masjid berusaha memenuhi tuntutan untuk "memakmurkan masjid", artinya setiap masjid hendaknya diisi dengan kegiatan-kegiatan, baik yang terkait dengan ibadah maupun persoalan muamalah.

Selain dari kegiatan ibadah rutin (shalat 5 waktu) yang memang sudah terjadwal secara ketat, dibeberapa masjid khususnya di pusat kota London menyuguhkan program yang sudah tertata secara rapi,baikyang bersifat rutin maupun yang insidentil. Misalnya pengajian rutin yang terkait dengan keilmuan dalam bidang "al-Quran", mulai dari belajar "membaca al-Quran" hingga ke pembelajaran "Tafsir al-Quran" semuanya sudah terjadwal, demikian halnya pembelajaran ilmu yang lain, seperti alHadits.Ada juga programlain yang menarik, yaitu para pengurus menyiapkan program "Kursus untuk belajar tentang Islam". Siapa saja yang ingin belajar dan mendalami "Islam", dipersilahkan mengikuti kursus tersebut secara gratis.

Tenaga yang digunakan untuk mengisi kegiatan tersebut dimbil dari para profesional di bidangnya, mereka memiliki stock sumber daya manusia (SDM) yang kapabel, kebanyakan dari alumni Mesir,
Fakistan, Sudan dan dari Eropa sendiri. Para pengasuh materi tersebut dibayar (digaji) oleh pengurus masjid, ada yang kontrak dengan limit waktu tertentu, dan ada pula yang sudah menjadi tenaga tetap.

Program dakwah keagamaan yang diimplementasikan dalam bentuk kegiatankegiatan rutin dan insidentil tersebut bisa berjalan dengan baik, karena suport pembiayaan dari pengurus masjid. Suport dana tersebut tidak menjadi masalah, karena pihak masjid sendiri memilik sumber-sumber ekonomi dari berbagai sektor. Misalnya, Masjid Islamic Centre United Kingdom (ICUK) memiliki tempat (toko) yang dipersewakan, dan tempat restoran, demikian juga persewaan tempat Hall untuk kegiatan-kegiatan atau acara tertentu dan sebagainya. Belum termasuk donatur dari para demawan dan sumbangan lain yang tidak mengikat. Sumber-sumber ekonomi inilah yang membackup seluruh pembiayaan yang terkait dengan masjid, termasuk kegiatan-kegiatan dakwah Islmaiyah.

Ada kegiatan yang tampak sederhana, tapi cukup menarik dan menantang, yaitu "Dakwah Table", yaitu suatu formula dakwah yang dilakukan di pinggir atau teras sepanjang pertokoan di pusat kota London dengan menyiapkan meja (table), dilengkapi dengan brosur-brosur tentang Islam, dan dipandu oleh bebrapa tenaga khusus. Brosurbrosur tersebut dibagi kepada khalayak atau kepada orang-orang yang kebetulan lewat di depannya.

Tenaga khusus terdiri atas 4 - 5 orang yang masing-masing memiliki job tersendiri. Dua - tiga orang yang ditugaskan menyapa orang-orang yang lewat dan membagikan 
brosur, bahkan sekaligus mengajak untuk belajar tentang Islam.Kemudian 2 orang tanaga khusus yang disiapkan untuk memberi penjelasan tentang Islam kepada yang mau singgah dan bersedia mendengarkan.

Model "dakwahtable"tersebutmerupakan adopsi dari cara-cara yang dilakukan oleh para marketing di perusahaan yang bergerak di bidang industri/perdagangan.Impaknya dirasakan banyak manfaatnya, yaitu: pertama, ada kesempatan mensosialisasikan Islam di tengah masyarakat sekuler dan cenderung tidak beragama; kedua, sosialisasi berimbas pada adanya masyarakat yang ingin mengetahui lebih dalam tentang Islam setelah menerima penjelasan singkat di "dakwah table"; ketiga, buah dari kegiatan tersebut berimbas pada bertambahnya jumlah penganjut Islam dari tahun ke tahun, yang cukup membantu menggerakkan dan meningkatkan jumlah angka statistik penganut Islam di United Kingdom sepuluh tahun terakhir. Jadi rekayasa model dakwah ke depan seyogyanya terus dilakukan dan menjadi keharusan untuk menjadikan Islam sebagai magnet kebaikan.

\section{Merajut Formulasi Pendidikan Agama dan Keagamaan}

Apa yang menjadi kegelisahan warga negara Indonesia di United Kingdom tentang pendidikan putra-putrinya, bukanlah dari sisi pendidikan umum yang diperoleh, tetapi justru pendidikan agama. Orang tua murid menggelisahkan sistem pendidikan agama yang diterapkan oleh sekolahsekolah di United Kingdom. Sebagaimana yang dikemukakan sebelumnya, bahwa pembelajaran agama di sekolah dilakukan bukan dalam ranah ritual, melainkan kajian keagamaan secara ilmu pengetahuan. Semua murid mendapatkan pelajaran agama dari semua agama agar mereka tahu realitas keagamaan. Misalnya, guru mengajarkan "Islam" tuhannya siapa? "Kristen" tuhannya siapa, demikian juga Hindu.

Jadi tidak ada mata pelajaran agama Islam atau Kristen, dan yang ada adalah mata pelajaran agama. Namun demikian jika orang tua murid merasa keberatan anaknya mendapatkan pelajaran agama, mereka bisa minta ke sekolah untuk tidak memberikan pelajaran agama kepada anaknya. Ketika tiba waktu pelajaran agama, si murid bisa keluar ruangan (kelas), dan kembali masuk setelah pelajaran berikutnya. Jadi tidak ada ikatan apapun apalagi yang namanya pemaksaan, pilihan penentuan menerima atau tidak pelajaran agama tersebut diserahkan kembali kepada orang tua murid.

Kenyataan itu, para orang tua murid, secara khusus warga negara Indonesia yang bermukim di London United Kingdom dan sekitarnya merindukan kehadiran lembaga pendidikan yang didalamnya meng-ajarkan pelajaran agama lebih dalam dari yang diperoleh sekarang. Mereka menginginkan ada lembaga khusus yang punya ciri keIndonesiaan misalnya "Sekolah Indonesia", sebagaimana yang terdapat di negara lain. Idealnya memang seperti itu, dan yang memiliki otoritas adalah pihak perwakilan pemerintah di United Kingdom dalam hal ini "Kedutaan Besar Republik Indonesia (KBRI). Keinginan untuk mendirikan "Sokolah Indonesia" baru pada tahap wacana, tetapi tidak menutup kemungkinan untuk merealisasikannya pada tahun-tahun mendatang, karena sudah ada pembicaraan awal oleh para pengurus Indonesia Islamic 
Centre (IIC) dengan Bapak H. M. Yusuf Kalla (JK) ketika beliau berkunjung ke Inggeris tahun 2015.

Terkait dengan persoalan ini merupkan kebutuhan yang prioritas, apalagi dalam kaitannya dengan merancang hari esok yang lebih baik yang berangkat dari dunia pendidikan, sebagai alternatif untuk merespons kebutuhan warga Indonesia. ${ }^{17}$ Kalau "sekolah Indonesia" terealisir, berarti sudah bisa diharapkan menjawab kebutuhan warga Indonesia, khususnya di bidang pendidikan agama.

Lantas bagaimana dengan pendidikan Keagamaan ? apakah harus berhenti ? pertanyaan tersebut tentu bisa dijawab, bahwa pendidikan keagamaan bisa jalan berbarengan dengan penyelenggaraan pendidikan agama secara formal di sekolah, karena disamping konsepnya berbeda wujud palaksanaannya juga berbeda. Pendidikan agama diselenggarakan secara formal di sekolah formal, tentu aturan mainnya mengacu pada ketentuan yang ada, termasuk di dalamnya acuan kurikulum. Sementara pendidikan keagamaan, penyelenggaraannya ada yang dilakukan di sekolah formal, tetapi dalam hal ini terbatas pada pendidikan kepesantrenan, tetapi diperbolehkan juga melakukan di luar sekolah formal, yaitu yang diselenggarakan oleh kelompok-kelompok paguyuban tertentu, misalnya majelis taklim dan semacamnya, sebagaimana yang diatur oleh Undang-undang pendidikan nasional nomor 57 tahun 2014.

${ }^{17}$ Harold G. Shane. The Education Significance of the Future. (terjemahan) M. Ansyar, Arti Pendidikan Bagi Masa Depan. Jakarta: PT. Raja Grafindo Persada, Ed. 1, Cetakan 2, tahun 2002. h. $17-22$

\section{PENUTUP}

Kronologi terbentuk dan bergabungnya dalam kelompok-kelompok paguyuban dari warga negara Indonesia yang bermukim di United Kingdom untuk membuat kegiatankegiatan keagamaan, khususnya pendidikan keagamaan, dipengaruhi oleh beberapa hal, yaitu: Pertama, adanya kerinduan untuk berkumpul bersama sebangsa setanah air, sebagaimana kebiasaan-kebiasaan lama ketika berada di Indonesia. Suasana keindonesiaan yang didalamnya ada muatan tawa, canda, dan semua keramahan menjadi dorongan yang kuat untuk merajutnya, sehingga muncullah beberapa kelompok paguyuban di Inggeris, atau London dan sekitarnya. Kedua, Kelompok-kelompok Paguyuban yang dibentuk warga negara Indonesia di Inggeris merupakan suatu jawaban atas pemenuhan kebutuhan rohani, khususnya siraman rohani keagamaan, karena kondisi dan suasana yang dirasakan baik di tempat kerja maupun di kampuskampus tempat melanjutkan pendidikan tidak ada fasilitas atau pelayanan seperti itu. Sebagai alternatif pilihan adalah bergabung dengan paguyuban Indonesia yang memang memberikan pelayanan pendidikan keagamaan. Ketiga, Kondisi persekolahan di Ingeris membuat kegelisahan bagi para orang tua murid dari Indonesia, karena ada kebutuhan lain, terutama kebutuhan pendidikan agama tidak terpenuhi. Salah satu alternatifnya adalah dengan bergabung di kelompok paguyuban muslim Indoensia.

Jadi terdapat adanya ikatan emosionaldan rasional yang menjadi motor penggerak terbentuk dan bergabungnya dalam kelompok paguyuban warga negara Indonesia untuk menyelenggarakan 
pendidikan keagamaan. Penyelenggaraan pendidikan keagamaan yang dilakukan oleh komunitas muslim Insdonesia di Inggeris masih sebatas kegiatan pengajian rutin di tempat paguyuban masing-masing, dan penyelenggaraan peringatan ritual HariHari besar Islam yang bersifat insidentil. Kegiatan-kegiatan tersebut belum terlalu istimewasebagaimanahalnyayangdilakukan oleh komunitas muslim United Kingdom. Kegiatan ini baru pada taraf menjawab persoalan aktualisasi diri dan penguatan identitas diri, demikian juga pemenuhan kebutuhann pendidikan keagamaan bagi putra-putrinya. Pilihan ini terkait dengan kondisi yang mengitari dimana komunitas muslim Indonesia dalam posisi minoritas di tengah-tengah masyarakat yang mayoritas sekuler. Upaya untuk meningkatkan ke arah yang lebih baik sudah dikondisikan dalam suatu tatanan rencana pengembangan ke masa datang. Pergerakan ke arah situ telah dimulai walaupun baru tahap pembicaraan awal dengan para penentu kebijakan ditanah air (Indonesia), signal-signal kecerahan telah diberikan, dan tinggal menunggu tindak lanjutnya.

Kehadiran komunitas muslim Indonesia di United Kingdom merupakan aset sekaligus modal sosial yang bisa memberi kontribusi tersendiri dalam pembangunan. Apalagi ketika komunitas muslim Indonesia mengkondisikan berbagai kegiatan kemasyarakatan keagamaan, khususnya pendidikann keagamaan. Beberapa hal yang menjadi pendukung, terutama dari aspek psychologis dengan alasan rasional sulit terhindarkan, dorongan keinginan berkumpul bersama di rantau selalu muncul, karena ada suasana keIndonesiaan yang ingin dirasakan. Faktor pendukung lainnya adalah pemenuhan kebutuhan rohaniyah sebagai muslim, tentu kelompok paguyuban menjadi alternatif pilihan, karena adanya ruang pelayanan yang bisa memenuhinya. Tempat kegiatan juga menjadi faktor pendukung, karena kegiatan pelayanan pendidikan keagamaan bisa dimobilisasi dari situ.

Terlepas dari adanya faktor pendukung, dari sisi yang lain ada juga faktor penghambatnya, yaitu:Jumlah warga negara Indonesia di United Kingdom semakin bertambah dan tersebar di beberapa negara bagian atau propinsi. Kondisi tersebut menjadi faktor yang bisa menghambat terlaksananya kegiatan, akibatnya membuat sebagian warga agak malas mengikuti pertemuan bulanan tersebut; Kesibukan masing-masing warga menjadi pemicu adanya faktor penghambat, sehingga waktu untuk menghadiri kegiatan di kelompok paguyubannya tidak bisa terpenuhi; Belum ada satu wadah yang bisa menghimpun warga negara Indonesia, yang secara khusus memberikan pelayanan pendidikan agama secara formal melalui "sekolah Indonesia", sebagaimana yang terdapat di negaranegara lain.

\section{UCAPAN TERIMA KASIH}

Tulisan ini rampung berkat bantuan dan jasa dari berbagai pihak, terutama: Kepala Badan Litbang dan Diklat Kementerian Agama, Kepala Puslitbang Pendidikan Agama dan Kegamaan beserta staf, Kepala Balai Litbang Agama Makassar, Staf Kedutaan Besar Republik Indonesia di United Kingdom, Para pengelola kelompok paguyuban Muslim Indonesia di United Kingdom, terkhusus Prof. Dr. Hadi Susanto, 
dan semua pihak yang tidak sempat disebut. Jasa baik tentu tidak akan terlupakan, dan saya menghaturkan terima kasih sedalamdalamnya.

\section{DAFTAR PUSTAKA}

Awad, Abdul Karim. (2015): The Role of The Mosque in $21^{\text {st }}$ Century Britain. Message of Islam, UK.

Bogdan, Robert dan Steven J. Taylor. (1993): Metode Penelitian Kualitatif, Surabaya: Usaha Nasional.

Harold G. Shane. The Education Significance of the Future. (terjemahan) M. Ansyar. (2008): Arti Pendidikan Bagi Masa Depan. Jakarta: PT. Raja Grafindo Persada, Ed. 1, Cetakan 2.

Huntington, Samuel P. (2005): "Benturan Antar Peradaban dan Masa Depan Politik Dunia. Yogyakarta: Qalam

Ismail, Arifuddin Ismail. (2011): "Majelis Taklim Hidayatullah di Perusahaan Non Muslim Kudus" di dalam "Jurnal al-Qalam" Volume 17 Nomor 2. Juli - Desember.

Khosin, Wahid. (2008): Pendidikan Keagamaan Pada Komunitas Anak Jalanan. Di dalam "Edukasi" jurnal Penelitian Agama dan Keagamaan, volume 6 nomor 3, JuliSeptember.
Mudjahirin Thohir. (2002): "Kehidupan Keagamaan Orang Jawa Pesisir: Studi Orang Islam Bangsri Jepara", Disertasi, Pascasarjana Universitas Indonesiajakarta.

Naisbit,John. (1988): Global Paradox. London: Nicholas Brealy Publishing.

Safriadi. (2008): Keikutsertaa Masyarakat dalam membangun Kualitas Pelayanan Publik. Blog di WordPress.

Ta'rif. (2008): “Pelayanan Pendidikan Keagamaan Komunitas Muslim Minoritas di Bali". Di dalam Jurnal Edukasi Volume 6 nomor 3 Juli-September.

Wardana, Amika. (2013): Living in Between: The Multiple Integration Trajectories of The London Indonesian Muslim Imigrants. Departemen of Sociology. University of Essex.

William Daviddow H. \& Bra Uttal. (1989): Total Custumers Service the Ultimate Weapon., New York: The Free Press.

Disadur dari https://en.wikipedia.org/wiki/ Countries_of_United_Kingdom

Diambil dari http://fstar.hol.es/2014/08

Diambil dari Internet, Dokumen sosialisasi Peraturan Pemerintah nomor 55 tahun 2007 tentang Pendidikan Agama dan Pendidikan Keagamaan 